\title{
Effect of Growth Conditions and Surface Characteristics of Aquatic Bacteria on Their Attachment to Solid Surfaces
}

\author{
By SHARRON MCELDOWNEY ${ }^{1,2 * \dagger}$ AND MADILYN FLETCHER ${ }^{1}$ \\ ${ }^{1}$ Department of Environmental Sciences, University of Warwick, Coventry CV4 7AL, UK \\ ${ }^{2}$ Freshwater Biological Association, River Laboratory, Wareham, Dorset BH20 6BB, UK
}

(Received 12 June 1985 ; revised 27 August 1985)

\begin{abstract}
The physico-chemical basis for the effects of nutrient conditions on the attachment of four freshwater isolates, Pseudomonas fuorescens, Enterobacter cloacae, Chromobacterium sp. and Flexibacter sp., to hydrophobic (PD) and relatively hydrophilic (TCD) polystyrene surfaces was investigated. Different nutrient conditions and growth rates resulted in changes in the physicochemistry of the bacterial surfaces, measured either by liquid contact angles on lawns of cells or by hydrophobic and electrostatic interaction chromatography of cells, and in different levels of attachment to the substrata. The phenotypic changes in cell surfaces and the levels of attachment were different for each species. Levels of bacterial adhesion differed for the two substrata, indicating different adhesion interactions with PD and TCD surfaces. Treatment of attached cells with chloramphenicol did not cause detachment of any of the bacteria from PD or TCD, whereas periodate and protease treatment removed some attached cells, the degree of detachment depending on the species. The presence of complex organic molecules, in the liquid phase and conditioning the solid surface, influenced the extent of bacterial attachment, the effect depending on the substratum, organic concentration and bacterial species. The results suggest that changes in nutrient conditions in natural aquatic habitats will affect the attachment of individual bacterial species differently, thus influencing the population structure of developing biofilms.
\end{abstract}

\section{INTRODUCTION}

Bacterial attachment to solid surfaces in aqueous systems is a complex interaction between the bacterium, the solid substratum and the liquid phase. Each of these components can vary with changes in environmental conditions, which will in turn affect attachment processes. Bacteria react physiologically to fluctuations in environmental conditions, such as changes in nutrient concentrations. The macromolecular components of bacterial surfaces, e.g. lipopolysaccharide, protein and exopolymers, have been shown to vary in quantity and composition with growth conditions (Ellwood \& Tempest, 1972; Jarman et al., 1978) and with growth rate in continuous culture (Ellwood \& Tempest, 1972). The effects vary with species. Differences in cell wall or polymer constitution appear to be reflected in the physico-chemical characteristics of the cells, e.g. through differences in electrophoretic mobility (Plummer et al., 1962; Marshall, 1967) or hydrophobicity (Rosenberg et al., 1982). The importance of cell surface chemical and physical properties in bacterial attachment interactions has been demonstrated both experimentally (Rosenberg, 1981; Hogt et al., 1982) and theoretically (Lips \& Jessup, 1979; Pethica, 1980) although the chemical bases for these interactions are still largely undetermined.

\footnotetext{
$\dagger$ Requests for offprints should be sent to the Coventry address.

Abbreviations: EIC, electrostatic interaction chromatography; HIC, hydrophobic interaction chromatography; PD, polystyrene Petri dish; TCD, tissue culture treated polystyrene Petri dish.
} 
Organic substances can affect not only the bacteria (by serving as nutrients) but also the liquid and solid phases of the attachment interaction through their influence on thermodynamic parameters, e.g. surface tension. With a solid substratum, this involves the energeticallyfavoured irreversible adsorption of large macromolecules, sometimes called a conditioning film (Dexter, 1977). The amount and rate of adsorption of proteins is dependent on the solid surface involved (Baszkin \& Lyman, 1980), the macromolecular species adsorbed (Norde \& Lyklema, 1978), and the manner in which the macromolecule is anchored (Eirich, 1977). In general, high energy and high polarity substrata will adsorb macromolecules strongly, with a flattening of the macromolecules across the surface, while low energy, non-polar surfaces will bind macromolecules less strongly although a thicker layer may develop (Baier, 1981). A macromolecular conditioning film on a solid substratum presents a new set of surface characteristics to the bulk liquid phase. Thus, the electrostatic charge (Loeb \& Neihof, 1975) and the critical surface tension (an indication of surface free energy) (Baier, 1981) may change with the accumulation of a conditioning layer. Accordingly, a variety of protein conditioning layers, on surfaces such as polystyrene and glass, may both increase and inhibit the attachment of different bacterial species (Fletcher, 1976).

The aim of this study was to determine the physico-chemical basis for the effects of growth conditions on bacterial attachment to surfaces, and to examine the role played by polysaccharide and protein cell surface components in the attachment interaction. The influence of organic molecules on bacterial attachment was also investigated, particularly in relation to cell surface changes induced by different growth conditions.

\section{METHODS}

Organisms. The bacteria, isolated from the River Sowe at Baginton Weir, Coventry (Pringle \& Fletcher, 1983), were identified as Pseudomonas fluorescens, Enterobacter cloacae, Chromobacterium sp. and Flexibacter sp.

Batch cultures. The bacteria were cultured in a selection of minimal media containing different carbon sources and carbon: nitrogen ratios. The minimal media consisted of $0.544 \mathrm{~g} \mathrm{KH}_{2} \mathrm{PO}_{4}, \mathrm{pH} 7.4$, and $0.6 \mathrm{ml}$ of a salt solution consisting of $\left(1^{-1}\right) 10 \mathrm{~g} \mathrm{MgSO}_{4} .7 \mathrm{H}_{2} \mathrm{O}, 1.0 \mathrm{~g} \mathrm{MnCl}_{2} .4 \mathrm{H}_{2} \mathrm{O}, 0.4 \mathrm{~g} \mathrm{FeSO}_{4} .7 \mathrm{H}_{2} \mathrm{O}$ and $0.1 \mathrm{~g} \mathrm{CaCl}_{2} .2 \mathrm{H}_{2} \mathrm{O}$ in $100 \mathrm{ml}$ distilled water with the addition of one of the following: (i) $0.05 \mathrm{~g}$ glucose, $0.38 \mathrm{~g} \mathrm{NH}_{4} \mathrm{Cl}$ (carbon-limited); (ii) $0.2 \mathrm{~g}$ glucose, $0.02 \mathrm{~g} \mathrm{NH}_{4} \mathrm{Cl}$ (nitrogen-limited); (iii) $0.2 \mathrm{~g}$ glucose, $0.38 \mathrm{~g} \mathrm{NH}_{4} \mathrm{Cl}$ (carbon- and nitrogen-sufficient); (iv) $0.2 \mathrm{~g}$ glucose, $0.38 \mathrm{~g} \mathrm{NH}_{4} \mathrm{Cl}, 10 \%(\mathrm{v} / \mathrm{v})$ glycerol; (v) $1 \%$ (w/v) lactose, $0.38 \mathrm{~g} \mathrm{NH}_{4} \mathrm{Cl} ;(\mathrm{vi}) 1 \%$ (w/v) galactose, $0.38 \mathrm{~g} \mathrm{NH}_{4} \mathrm{Cl}$; (vii) $1 \%\left(\mathrm{w} / \mathrm{v}\right.$ ) mannose, $0.38 \mathrm{~g} \mathrm{NH}_{4} \mathrm{Cl}$; (viii) $1 \%\left(\mathrm{w} / \mathrm{v}\right.$ ) sucrose, $0.38 \mathrm{~g} \mathrm{NH}_{4} \mathrm{Cl}$.

After inoculation with $1 \mathrm{ml}$ of a stationary phase culture, cultures were grown in the test media for $24 \mathrm{~h}$, at $15^{\circ} \mathrm{C}$ on a rotary incubator at 150 r.p.m., before sampling. Chromobacterium sp. was sampled after both 24 and $48 \mathrm{~h}$ incubation.

The organisms were also grown to late stationary phase before sampling in a broth medium consisting of $0 \cdot 1 \%$ (w/v) bacteriological peptone and $0.07 \%(w / v)$ yeast extract (PYE) at $\mathrm{pH} 7.4$ at $15{ }^{\circ} \mathrm{C}$ on a rotary incubator at 150 r.p.m.

Continuous culture. The organisms were grown in continuous culture in PYE buffered at $\mathrm{pH} 7 \cdot 4\left(\mathrm{KH}_{2} \mathrm{PO}_{4}\right.$, $\left.5.44 \mathrm{~g}^{-1}\right)$ at a constant temperature of $15^{\circ} \mathrm{C}\left( \pm 2^{\circ} \mathrm{C}\right)$ maintained by a Churchill Chiller Thermocirculator and at a steady aeration rate. For each bacterial culture the dilution rate $(D)$ was changed successively from $0.05 \mathrm{~h}^{-1}$ to $0.1 \mathrm{~h}^{-1}$ to $0 \cdot 15 \mathrm{~h}^{-1}$ to $0 \cdot 2 \mathrm{~h}^{-1}$. At each dilution rate the cultures were sampled only after a minimum of three complete volume changes.

Attachment assays. The batch cultures or $100 \mathrm{ml}$ samples from the continuous cultures were harvested by centrifugation at $11000 \mathrm{~g}$. The cells were washed once in $0.01 \mathrm{M}-\mathrm{HEPES}$ buffer (Sigma), $\mathrm{pH} 7 \cdot 4$, and resuspended in (i) $0.01 \mathrm{M}$-HEPES buffer; (ii) $0.05 \%$ (w/v) peptone and $0.035 \%(\mathrm{w} / \mathrm{v})$ yeast extract powder ( $\frac{1}{2}$ PYE); or (iii) PYE broth, to an optical density of 0.1 at $540 \mathrm{~nm}$ in a colorimeter (Corning Colorimeter 252).

Samples $(5 \mathrm{ml})$ of the suspensions were then transferred to $5 \mathrm{~cm}$ polystyrene Petri dishes (PD) (Sterilin), a hydrophobic surface, or tissue culture treated polystyrene dishes (TCD) (Costar), a relatively hydrophilic surface; these served as the attachment substrata. Duplicate PD and TCD for each type of cell suspension were incubated for 5 and for $60 \mathrm{~min}$ at $15^{\circ} \mathrm{C}$ and then washed gently three times with $0.01 \mathrm{M}$-HEPES buffer ( $\mathrm{pH} 7 \cdot 4$ ) to remove loosely attached bacteria. The remaining attached bacteria were fixed with Bouin's fixative $(71 \%, \mathrm{v} / \mathrm{v}$, saturated aqueous picric acid solution; $24 \%, \mathrm{v} / \mathrm{v}$, formalin; $5 \%, \mathrm{v} / \mathrm{v}$, acetic acid) and stained with crystal violet $\left(5 \mathrm{~g}^{-1}\right)$ (Fletcher, 1976). Bacterial attachment was estimated indirectly by measuring the $A_{590}$ of the stained attached bacteria. Four readings of randomly selected areas were taken from each of the duplicate dishes.

Results were expressed either as $A_{590}\left(\times 10^{3}\right)$ of the attached cells or, for those cells attached in $\frac{1}{2} \mathrm{PYE}$ and PYE, as an index of attachment $\left(I_{\mathrm{i}}\right) . I_{\mathrm{a}}$ was calculated as the ratio of the $A_{590}\left(\times 10^{3}\right)$ of the test substratum to that 
of the corresponding control substratum, e.g. cells attached in PYE to PD/cells attached in buffer to PD. $I_{\mathrm{a}}$ values of 1 were recorded for treatments whose $95 \%$ confidence limits of the mean $(n=8)$ overlapped with that of the controls; any value of $I_{\mathrm{a}}$ outside these limits was considered to represent an effect.

Detachment assays. Cells grown to late stationary phase in PYE broth were centrifuged, washed once in $0.01 \mathrm{M}$ -

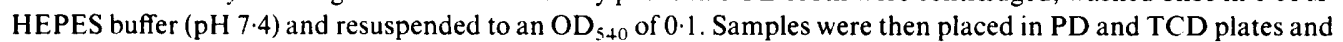
incubated for $1 \mathrm{~h}$ as described for the attachment assay. One set of duplicate plates for each bacterial species was then washed (three times with $0.01 \mathrm{M}-\mathrm{HEPES}, \mathrm{pH} 7.4$ ) and stained, whereas the remaining duplicate plates were washed as above and then exposed to $5 \mathrm{ml}$ samples of one of the following in 0.01 M-HEPES buffer (pH 7.4): (i) control; (ii) $5 \mu \mathrm{g}$ chloramphenicol $\mathrm{ml}^{-1}$; (iii) $1 \%$ (w/v) sodium periodate; (iv) 1 unit per $5 \mathrm{ml}$ bacterial protease. The duplicate plates were incubated at $15^{\circ} \mathrm{C}$ for a further $1 \mathrm{~h}$ before washing and staining as in the attachment assay.

The results were expressed as PD $I_{\mathrm{d}}$ and TCD $I_{\mathrm{d}}$, i.e. indices of detachment. $I_{\mathrm{d}}$ values were determined in an analogous way to $I_{\mathrm{a}}$ values.

Measurement of contact angle $(\theta)$ of lawns of cells. A method was developed based on that of Absolom et al. (1983). Bacteria were harvested from batch minimal media cultures by centrifugation, washed once in $0 \cdot 15 \mathrm{M}-\mathrm{NaCl}$, and resuspended to a concentration of approximately $10^{10}$ cells ml-1 in $2 \mathrm{ml} 0 \cdot 15 \mathrm{M}-\mathrm{NaCl}$. Drops of the cell suspension were then spread over an agar-covered slide $(2 \%, \mathrm{w} / \mathrm{v}$, lonagar $+10 \%, \mathrm{w} / \mathrm{v}$, glycerol in $0 \cdot 15 \mathrm{M}-\mathrm{NaCl})$, and allowed to dry until the cells took on a matt appearance.

The advancing contact angles of $10 \mu 1$ drops of $0.15 \mathrm{M}-\mathrm{NaCl}\left(\theta_{\mathrm{s}}\right)$ were then measured every $10 \mathrm{~min}$, using a vernier microscope with a goniometer eyepiece (PTI). Duplicate measurements were made at each interval and were considered reliable if they did not vary by more than $\pm 0 \cdot 5^{\circ}$. No two measurements were made on the same area of cells. When a plateau value of $\theta_{\mathrm{s}}$ was reached $\left( \pm 1^{\circ}\right)$ it was taken to represent the saline contact angle of the lawn of cells.

Measurements of contact angle of clean and treated PD and TCD surfaces. To evaluate the effect of adsorbed medium components on the substratum surface, $\theta$ values were measured on medium-coated surfaces. PD and TCD materials were incubated in $5 \mathrm{ml}$ samples of PYE or $\frac{1}{2} \mathrm{PYE}$ at $15^{\circ} \mathrm{C}$ for $60 \mathrm{~min}$ before being washed three times with 0.01 M-HEPES ( $\mathrm{pH} 7 \cdot 4$ ). The treated surfaces were then allowed to air-dry for a minimum of $2 \mathrm{~h}$ at room temperature. The advancing water contact angle $\left(\theta_{\mathrm{H}_{2} \mathrm{O}}\right)$ of a $10 \mu \mathrm{l}$ drop of distilled water on clean and treated PD and TCD surfaces was measured as above except that 10 separate measurements were made for each surface, and a mean value was calculated.

Measurement of liquid surface tension. The liquid surface tension $\left(\gamma_{\mathrm{LV}}\right)$ of $0.01 \mathrm{M}$-HEPES buffer, $\frac{1}{2} \mathrm{PYE}$ and PYE were measured using a platinum loop and torsion balance (White Electrical Instruments).

Hydrophobic, cationic and anionic chromatography of cells. The method for investigating the hydrophobic, cationic and anionic interactions of different bacterial species was adapted from the methods of Dählback et al. (1981) and Pederson (1980).

Glass wool-plugged Pasteur pipettes were washed with $95 \%(\mathrm{v} / \mathrm{v})$ ethanol followed by $0 \cdot 1 \mathrm{M}-\mathrm{NaCl}$. PhenylSepharose CL-4B gel (Sigma) for hydrophobic interaction chromatography (HIC) was diluted $1: 1$ with $0 \cdot 1 \mathrm{M}-\mathrm{NaCl}$ $(w / v)$, degassed and packed into the pipettes. Similarly, for electrostatic interaction chromatography (EIC), $1 \mathrm{ml}$ quantities of anion exchange resin (Dowex $1 \times 8$ mesh size 100/200, 80-150 $\mu$ l) (Sigma) or cation exchange resin (Dowex 50W $\times 8$ mesh size 100/200,80-150 $\mu$ l) (Sigma) were suspended in $1 \mathrm{ml} \mathrm{0} 1 \mathrm{M}-\mathrm{NaCl}$, degassed and packed into the Pasteur pipettes. These two types of column were used for EIC.

Cells were harvested from continuous culture samples $(100 \mathrm{ml})$ by centrifugation, resuspended in $20 \mathrm{ml} \mathrm{KH}_{2} \mathrm{PO}_{+}$buffer $\left(5.4 \mathrm{~g} \mathrm{l}^{-1}, \mathrm{pH} \mathrm{7.4}\right)$ and incubated at $15^{\circ} \mathrm{C}$ for $2 \mathrm{~h}$ after the addition of $1 \mu \mathrm{Ci} \mathrm{L}-\left[{ }^{3} \mathrm{H}\right] l e u c i n e$ $\mathrm{ml}^{-1}$ (specific activity $46 \mathrm{Ci} \mathrm{mmol}^{-1} ; 1702 \mathrm{GBq}$ ) (Amersham). The ${ }^{3} \mathrm{H}$-labelled bacteria were then washed three times by centrifuging with $0 \cdot 1 \mathrm{M}-\mathrm{NaCl}$ to remove unmetabolized label, and resuspended in $0 \cdot 1 \mathrm{M}-\mathrm{NaCl}$ to a volume of $10 \mathrm{ml}$, giving a final cell density of approximately $10^{9}$ cells $\mathrm{ml}^{-1}$. Samples $(1 \mathrm{ml})$ of the suspensions were applied to duplicate HIC and EIC columns, followed by $3 \mathrm{ml} 0 \cdot 1 \mathrm{M}-\mathrm{NaCl}$. Two further $4 \mathrm{ml}$ samples of $0 \cdot 1 \mathrm{M}-\mathrm{NaCl}$ were run through the columns. The eluates from all these columns were collected separately.

Four replicate $100 \mu \mathrm{l}$ samples from each eluate and the original cell suspension were individually counted for radioactivity, using $10 \mathrm{ml}$ of a scintillation cocktail consisting of toluene/Triton X-100 (2:1, v/v) (scintillation grade) and $0.6 \%(\mathrm{w} / \mathrm{v})$ of the scintillator butyl PBD (Fisons). Counts were made with a liquid scintillation counter (System LS 7000, Beckman Instruments) and the extent of quenching was determined by the $\mathrm{H}$ number system (Horrocks, 1977). Counts were repeated if there was a discrepancy $> \pm 5 \%$ between replicate values. The final eluate had counts normally not much above background level. The extent of leakage from labelled cells was determined by counting $100 \mu \mathrm{l}$ duplicate samples of the final wash supernatant; $10 \%$ leakage was the maximum considered acceptable.

The results were expressed in terms of the percentage of counts remaining in the column. The results from duplicate columns were considered consistent if they differed by no more than $5 \%$. The higher the percentage of cells remaining in the HIC and EIC columns, the greater the hydrophobic or electrostatic interactions, respectively. 


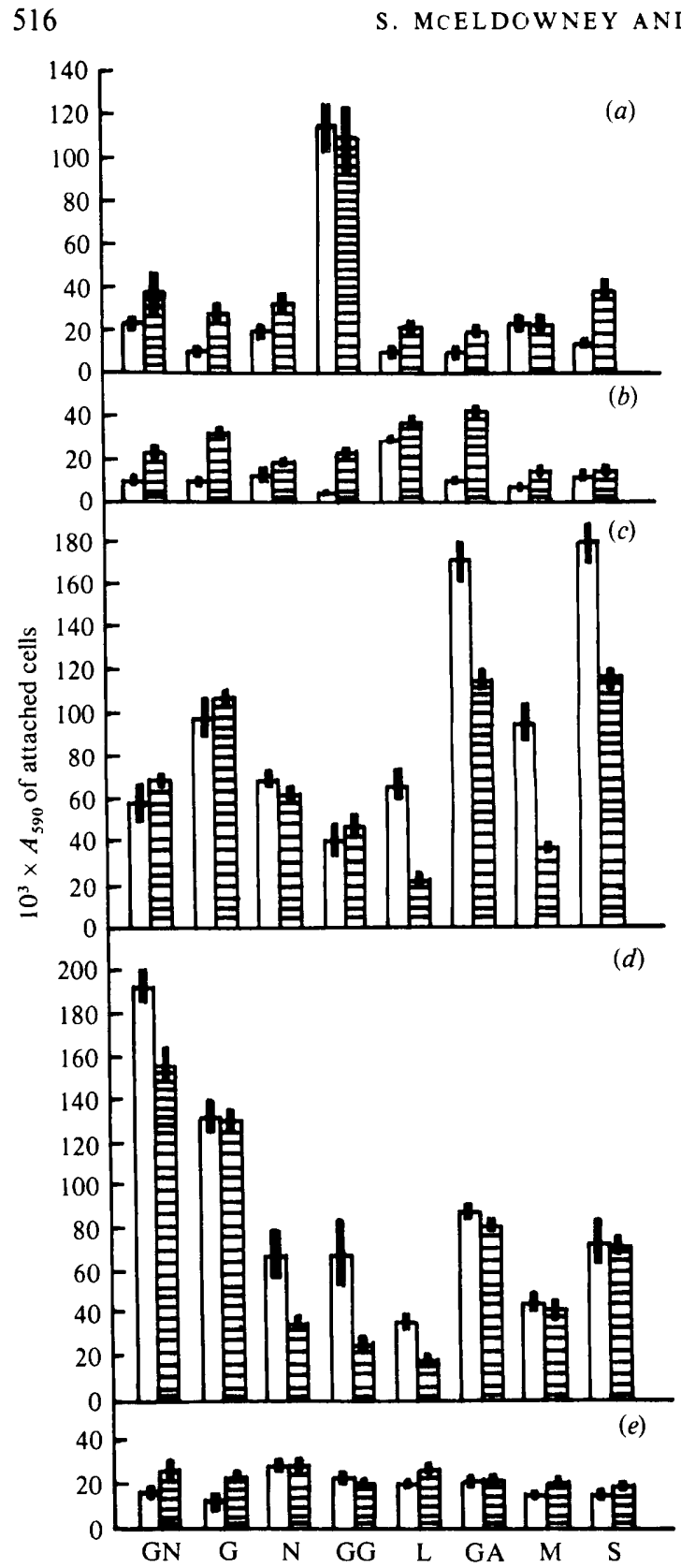

Fig. 1. Effect of carbon: nitrogen ratio and carbon source on the attachment of $(a) P$. fluorescens, $(b)$ E. cloacae, (c) Chromobacterium sp. after $24 \mathrm{~h}$ growth, (d) Chromobacterium sp. after $48 \mathrm{~h}$ growth and (e) Flexibacter sp. The nutrient conditions were glucose and nitrogen sufficient $(G N)$, glucose-limited $(G)$, nitrogen-limited $(N)$, glucose and glycerol (GG), lactose (L), galactose (GA), mannose (M) and sucrose (S). $\square$, Cells attached to the PD surface; 自, cells attached to the TCD surface; error bars define the $95 \%$ confidence limits of the mean $(n=8)$.

\section{RESULTS}

Effect of carbon source and carbon: nitrogen ratio on bacterial attachment and cell surface characteristics

Bacterial growth in media with different carbon:nitrogen ratio and carbon source had a marked effect on both the attachment of bacteria and the bacterial cell surface characteristics.

The four bacterial species investigated, P. fuorescens, E. cloacae, Chromobacterium sp. and Flexibacter sp., all reacted differently, with respect to attachment ability, to changes in culture conditions (Fig. 1). The variations in adhesion could be very large, e.g. P. fluorescens attached in high numbers after growth in glucose with glycerol and in relatively low numbers with the other culture conditions (Fig. 1 a). Such differences were found for all species; however, the strains did 
Table 1. Effect of carbon : nitrogen ratio and carbon source on the cell surface characteristics (measured by saline contact angles) of P. fluorescens, E. cloacae, Chromobacterium sp. and Flexibacter $s p$.

Saline contact angle on lawns of cells $\left(\theta_{s}\right)$

Carbon: nitrogen ratio or carbon source

Glucose + nitrogen excess Glucose-limited, nitrogen excess Nitrogen-limited, glucose excess Glucose + glycerol

Lactose

Galactose

Mannose

Sucrose
Chromohacterium sp.*

\begin{tabular}{|c|c|c|c|c|}
\hline \multirow[b]{2}{*}{ P. fluorescens } & \multirow[b]{2}{*}{ E. cloacae } & \multicolumn{2}{|c|}{ Chromohacterium sp.* } & \multirow[b]{2}{*}{ Flexibacter sp. } \\
\hline & & $24 \mathrm{~h}$ & $48 \mathrm{~h}$ & \\
\hline $17 \cdot 5$ & $14 \cdot 5$ & 20 & 38 & $19 \cdot 5$ \\
\hline $10 \cdot 0$ & $10 \cdot 0$ & 59 & $40 \cdot 5$ & $13 \cdot 0$ \\
\hline $16 \cdot 5$ & $12 \cdot 5$ & $32 \cdot 5$ & 30 & $21 \cdot 0$ \\
\hline $9 \cdot 5$ & $10 \cdot 5$ & $52 \cdot 5$ & 29 & $13 \cdot 0$ \\
\hline 11.5 & $9 \cdot 0$ & 10.5 & 20 & $11 \cdot 0$ \\
\hline $9 \cdot 5$ & 14.0 & 75 & 42 & $13 \cdot 0$ \\
\hline $8 \cdot 5$ & $19 \cdot 0$ & 29 & $16 \cdot 5$ & $12 \cdot 5$ \\
\hline $17 \cdot 0$ & $13 \cdot 0$ & $44 \cdot 5$ & $27 \cdot 5$ & $11 \cdot 5$ \\
\hline
\end{tabular}

* $\theta_{\mathrm{s}}$ of Chromobacterium sp. after $24 \mathrm{~h}$ or $48 \mathrm{~h}$ growth in batch culture.

not all show the same attachment response to growth with a given medium composition. The organism least susceptible to large changes in attachment after growth in different nutrient conditions was Flexibacter sp. (Fig. le). Chromobacterium sp. showed considerable differences in attachment after growth for $24 \mathrm{~h}$ and for $48 \mathrm{~h}$ in most conditions tested; for example, after growth for $24 \mathrm{~h}$ in glucose- and nitrogen-sufficient medium, attachment was approximately a third of that after $48 \mathrm{~h}$ growth (Figs $1 c$ and $1 d$ ).

The extent of attachment to the PD and TCD surfaces was independently variable with the culture conditions, e.g. E. cloacae after growth in galactose attached to TCD in numbers approximately fourfold higher than those obtained with PD whereas after growth in sucrose medium there was only a slight difference between the two surfaces (Fig. $1 b$ ).

Differences in bacterial cell surface characteristics were demonstrated by saline contact angle $\left(\theta_{\mathrm{s}}\right)$ measurements on lawns of cells after growth in the different media (Table 1). Thus, $P$. fluorescens showed a range of $\theta_{\mathrm{s}}$ from $17.5^{\circ}$ after growth in glucose- and nitrogen-sufficient media to $8.5^{\circ}$ when mannose was the carbon source (Table 1). The largest differences were shown by Chromobacterium sp., which had $\theta_{\mathrm{s}}$ of $75^{\circ}$ after $24 \mathrm{~h}$ growth in galactose and $10.5^{\circ}$ after $24 \mathrm{~h}$ growth in lactose (Table 1). This bacterium was, in general, the most hydrophobic. The $\theta_{\mathrm{s}}$ for Chromobacterium sp. varied not only with growth condition, but also with culture age (i.e. after $24 \mathrm{~h}$ and $48 \mathrm{~h}$ growth; Table 1 ).

\section{Effect of growth rate on bacterial attachment and cell surface characteristics}

The effect of dilution rate in continuous culture on bacterial attachment in buffer varied with the organism as did its effect on bacterial cell surface characteristics, as measured by HIC and EIC (Table 2). The extent of attachment after both 5 and 60 min was affected by bacterial growth rate, although the differences were more pronounced at $60 \mathrm{~min}$. E. cloacae and Chromobacterium sp. (both of which often flocculated in PYE) showed the largest variations in cell surface characteristics, while the cell surface characteristics of the two non-flocculating species, i.e. P. fluorescens and Flexibacter sp., were more stable (Table $2 a, d$ ).

These two categories of flocculating and non-flocculating bacteria could be further subdivided, as one member of each category attached in large numbers, while relatively few cells of the other member attached to the solid surfaces. Thus, P. fluorescens and E. cloacae (Table $2 a$, $b$ ) attached in relatively low numbers to both surfaces at all dilution rates. Yet the fluctuations in these low attachment levels were accompanied by changes in HIC and EIC values, indicating changes in cell surface characteristics. By contrast, Chromobacterium sp. and Flexibacter sp. showed increased attachment to both surfaces with increases in dilution rate, reaching quite high attachment numbers at the two highest dilution rates. HIC and EIC values, and thus cell surface characteristics, also varied with dilution rate (Table $2 c, d$ ). 
Table 2. Effect of growth rate on cell surface characteristics, measured by interaction chromatography and attachment of the isolates

\begin{tabular}{|c|c|c|c|c|c|c|c|c|}
\hline \multirow[b]{3}{*}{ Species } & \multirow{3}{*}{$\begin{array}{l}\text { Chemostat } \\
\text { dilution } \\
\text { rate } \\
\left(\mathrm{h}^{-1}\right)\end{array}$} & \multicolumn{3}{|c|}{$\begin{array}{l}\text { Interaction chromatography } \\
\text { (percentage of counts } \\
\text { retained in columns) }\end{array}$} & \multicolumn{4}{|c|}{$10^{3} \times A_{590}$ of cells attached to:* } \\
\hline & & \multirow{2}{*}{$\begin{array}{l}\text { Hydrophobic } \\
\text { chromatography } \\
\text { column }\end{array}$} & \multirow{2}{*}{$\begin{array}{l}\text { Anion } \\
\text { exchange } \\
\text { resin }\end{array}$} & \multirow{2}{*}{$\begin{array}{l}\text { Cation } \\
\text { exchange } \\
\text { resin }\end{array}$} & \multicolumn{2}{|c|}{ PD } & \multicolumn{2}{|c|}{$\underbrace{T C D}$} \\
\hline & & & & & $5 \mathrm{~min}$ & $60 \mathrm{~min}$ & $5 \mathrm{~min}$ & $60 \mathrm{~min}$ \\
\hline P. fluorescens & 0.05 & $16 \cdot 1$ & $16 \cdot 5$ & $83 \cdot 0$ & $\begin{array}{c}12 \\
(+2)\end{array}$ & $\begin{array}{c}25 \\
(+3)\end{array}$ & $\begin{array}{c}21 \\
(+3)\end{array}$ & $\begin{array}{c}27 \\
(+3)\end{array}$ \\
\hline & $0 \cdot 1$ & $17 \cdot 9$ & $10 \cdot 2$ & 85.9 & $\begin{array}{c}6 \\
( \pm 3)\end{array}$ & $\begin{array}{c}30 \\
( \pm 7)\end{array}$ & $\begin{array}{c}14 \\
( \pm 0 \cdot 8)\end{array}$ & $\begin{array}{c}25 \\
( \pm 3)\end{array}$ \\
\hline & $0 \cdot 15$ & $12 \cdot 0$ & $2 \cdot 3$ & $77 \cdot 5$ & $\begin{array}{c}9 \\
( \pm 0.8)\end{array}$ & $\begin{array}{c}20 \\
( \pm 2)\end{array}$ & $\begin{array}{c}19 \\
( \pm 2)\end{array}$ & $\begin{array}{c}32 \\
( \pm 3)\end{array}$ \\
\hline & $0 \cdot 2$ & $14 \cdot 6$ & 8.9 & $84 \cdot 1$ & $\begin{array}{c}6 \\
( \pm 2)\end{array}$ & $\begin{array}{c}32 \\
( \pm 4)\end{array}$ & $\begin{array}{c}13 \\
( \pm 2)\end{array}$ & $\begin{array}{c}21 \\
( \pm 3)\end{array}$ \\
\hline E. cloacae & 0.05 & $45 \cdot 0$ & $33 \cdot 1$ & $80 \cdot 1$ & $\begin{array}{c}8 \\
( \pm 2)\end{array}$ & $\begin{array}{c}31 \\
( \pm 3)\end{array}$ & $\begin{array}{c}19 \\
( \pm 3)\end{array}$ & $\begin{array}{c}43 \\
( \pm 4)\end{array}$ \\
\hline & $0 \cdot 1$ & 79.9 & 79.0 & $92 \cdot 9$ & $\begin{array}{c}7 \\
\pm 0.8)\end{array}$ & $\begin{array}{c}18 \\
( \pm 2)\end{array}$ & $\begin{array}{c}17 \\
( \pm 0.8)\end{array}$ & $\begin{array}{c}31 \\
( \pm 0.5)\end{array}$ \\
\hline & $0 \cdot 15$ & $86 \cdot 2$ & 1.8 & $62 \cdot 8$ & $\begin{array}{c}3 \\
( \pm 3)\end{array}$ & $\begin{array}{c}5 \\
( \pm 3)\end{array}$ & $\begin{array}{c}17 \\
( \pm 3)\end{array}$ & $\begin{array}{c}24 \\
( \pm 3)\end{array}$ \\
\hline & $0 \cdot 2$ & $6 \cdot 4$ & 1.8 & $54 \cdot 4$ & $\begin{array}{c}5 \\
( \pm 0.8)\end{array}$ & $\begin{array}{c}8 \\
( \pm 0.5)\end{array}$ & $\begin{array}{c}17 \\
( \pm 2)\end{array}$ & $\begin{array}{c}22 \\
( \pm 4)\end{array}$ \\
\hline Chromobacterium sp. & 0.05 & $10 \cdot()$ & $32 \cdot 3$ & $6 \cdot 7$ & $\begin{array}{c}14 \\
( \pm 3)\end{array}$ & $\begin{array}{c}34 \\
( \pm 6)\end{array}$ & $\begin{array}{c}16 \\
( \pm 3)\end{array}$ & $\begin{array}{c}13 \\
( \pm 4)\end{array}$ \\
\hline & $0 \cdot 1$ & $32 \cdot 4$ & $24 \cdot 0$ & $21 \cdot 6$ & $\begin{array}{c}14 \\
( \pm 0 \cdot 8)\end{array}$ & $\begin{array}{c}37 \\
( \pm 2)\end{array}$ & $\begin{array}{c}25 \\
( \pm 2)\end{array}$ & $\begin{array}{c}39 \\
( \pm 3)\end{array}$ \\
\hline & $0 \cdot 15$ & $61 \cdot 4$ & $54 \cdot 7$ & $94 \cdot 9$ & $\begin{array}{c}21 \\
( \pm 4)\end{array}$ & $\begin{array}{c}70 \\
( \pm 3)\end{array}$ & $\begin{array}{c}23 \\
( \pm 4)\end{array}$ & $\begin{array}{c}59 \\
( \pm 5)\end{array}$ \\
\hline & $0 \cdot 2$ & $30 \cdot 0$ & $44 \cdot 4$ & $94 \cdot 1$ & $\begin{array}{c}27 \\
( \pm 3)\end{array}$ & $\begin{array}{c}84 \\
( \pm 8)\end{array}$ & $\begin{array}{c}29 \\
( \pm 0 \cdot 8)\end{array}$ & $\begin{array}{c}56 \\
( \pm 4)\end{array}$ \\
\hline Flexibacter sp. & $0 \cdot 05$ & $73 \cdot 1$ & $87 \cdot 6$ & $62 \cdot 4$ & $\begin{array}{c}9 \\
( \pm 2)\end{array}$ & $\begin{array}{c}15 \\
( \pm 3)\end{array}$ & $\begin{array}{c}7 \\
( \pm 3)\end{array}$ & $\begin{array}{c}7 \\
( \pm 3)\end{array}$ \\
\hline & $0 \cdot 1$ & $60 \cdot 2$ & $91 \cdot 5$ & $87 \cdot 0$ & $\begin{array}{c}13 \\
( \pm 2)\end{array}$ & $\begin{array}{c}51 \\
( \pm 5)\end{array}$ & $\begin{array}{c}13 \\
( \pm 2)\end{array}$ & $\begin{array}{c}76 \\
( \pm 7)\end{array}$ \\
\hline & $0 \cdot 15$ & $44 \cdot 2$ & 99.9 & 100 & $\begin{array}{c}10 \\
( \pm 0 \cdot 8)\end{array}$ & $\begin{array}{c}101 \\
( \pm 17)\end{array}$ & $\begin{array}{c}17 \\
( \pm 3)\end{array}$ & $\begin{array}{r}90 \\
( \pm 15)\end{array}$ \\
\hline & $0 \cdot 2$ & $55 \cdot 7$ & 62.7 & $73 \cdot 5$ & $\begin{array}{c}32 \\
( \pm 3)\end{array}$ & $\begin{array}{c}108 \\
( \pm 23)\end{array}$ & $\begin{array}{c}25 \\
( \pm 3)\end{array}$ & $\begin{array}{c}111 \\
( \pm 10)\end{array}$ \\
\hline
\end{tabular}

* Values in parentheses are $95 \%$ confidence limits of the mean $(n=8)$.

As with attachment after growth in different nutrient conditions (above), the attachment to PD and TCD surfaces after growth at different dilution rates was independently variable. For example, after $60 \mathrm{~min}$ attachment Chromobacterium sp. showed consistently higher attachment values to PD than to TCD at most dilution rates; however, at $D=0 \cdot 1 \mathrm{~h}^{-1}$ there was no apparent difference between the two surfaces (Table $2 c$ ).

\section{Effect of chloramphenicol, sodium periodate and protease on bacterial detachment from solid surfaces}

The inclusion of chloramphenicol $\left(5 \mu \mathrm{g} \mathrm{ml}^{-1}\right)$, an inhibitor of protein synthesis, in the detachment suspension did not cause removal of attached cells (Table 3). This was true for all four species and for both PD and TCD surfaces. Indeed, with P. fluorescens and E. cloacae the presence of chloramphenicol seemed to stabilize the film, reducing detachment compared to the control (Table 3).

In general, attachment to the TCD surface appeared to be more stable than that to the PD surface. Only $P$. fluorescens (Table 3 ) showed increased detachment from TCD for only protease 
Table 3. Effect of chloramphenicol, sodium periodate and protease on detachment of the isolates

$I_{\mathrm{d}}$ values were calculated as the ratio of the $A_{590}\left(\times 10^{3}\right)$ of the test substratum to that of the relevant control substratum. $I_{\mathrm{d}}$ values of 1 were recorded for treatments whose $95 \%$ confidence limits of the mean $(n=8)$ overlapped with that of the controls.

\begin{tabular}{|c|c|c|c|c|c|c|c|c|}
\hline \multirow[b]{2}{*}{ Treatment } & \multicolumn{2}{|c|}{ P. fluorescens } & \multicolumn{2}{|c|}{ E. cloacae } & \multicolumn{2}{|c|}{$\begin{array}{c}\text { Chromobacterium } \\
\text { sp. }\end{array}$} & \multicolumn{2}{|c|}{ Flexibacter sp. } \\
\hline & $\mathrm{PD} I_{\mathrm{d}}$ & $\operatorname{TCD} I_{\mathrm{d}}$ & PD $I_{\mathrm{d}}$ & $\operatorname{TCD} I_{\mathrm{d}}$ & $\mathrm{PD} I_{\mathrm{d}}$ & $\operatorname{TCD} I_{\mathrm{d}}$ & PD $I_{\mathrm{d}}$ & TCD $I_{\mathrm{c}}$ \\
\hline Chloramphenicol $\left(5 \mu \mathrm{g} \mathrm{ml}^{-1}\right)$ & $1 \cdot 5$ & $1 \cdot 1$ & $1 \cdot 35$ & 1 & 1 & 1 & 1 & 1 \\
\hline Sodium periodate $(1 \%, w / v)$ & 1 & 1 & 0.59 & 1 & 0.76 & 1 & $i$ & $i$ \\
\hline Protease ( 1 unit per $5 \mathrm{ml}$ ) & $0 \cdot 4$ & $0 \cdot 6$ & $0 \cdot 29$ & $i$ & 0.61 & 1 & 1 & 1 \\
\hline
\end{tabular}

Table 4. Effect of nutrients on the attachment of P. fluorescens and Chromobacterium sp. to PD and TCD after growth in continuous culture at various dilution rates

$I_{\mathrm{a}}$ values were calculated as the ratio of the $A_{590}\left(\times 10^{3}\right)$ of the test substratum to that of the relevant control substratum. $I_{\mathrm{i}}$ values of 1 were recorded for treatments whose $95 \%$ confidence limits of the mean $(n=8)$ overlapped with that of the controls.

\begin{tabular}{|c|c|c|c|c|c|c|c|c|c|}
\hline \multirow[b]{3}{*}{ Species } & \multirow{3}{*}{$\begin{array}{l}\text { Dilution } \\
\text { rate } \\
\left(\mathrm{h}^{-1}\right)\end{array}$} & \multicolumn{4}{|c|}{$\frac{1}{2} \mathrm{PYE}$} & \multicolumn{4}{|c|}{ PYE } \\
\hline & & \multicolumn{2}{|c|}{ PD $\underbrace{I_{\mathrm{i}}}$} & \multicolumn{2}{|c|}{$\operatorname{TCD} \underbrace{}_{\mathrm{a}}$} & \multicolumn{2}{|c|}{ PD $\underbrace{I_{\mathrm{a}}}$} & \multicolumn{2}{|c|}{$\operatorname{TCD} I_{\mathrm{a}}$} \\
\hline & & $5 \mathrm{~min}$ & $60 \mathrm{~min}$ & $5 \mathrm{~min}$ & $60 \mathrm{~min}$ & $5 \mathrm{~min}$ & $60 \mathrm{~min}$ & $5 \mathrm{~min}$ & $60 \mathrm{~min}$ \\
\hline \multirow[t]{4}{*}{ (a) P. fluorescens } & 0.05 & $1 \cdot 3$ & $1 \cdot 76$ & 1 & $2 \cdot 4$ & 1 & 1 & 1 & 1.9 \\
\hline & $0 \cdot 1$ & $2 \cdot 7$ & 1 & 1.4 & $2 \cdot 36$ & 1 & 1 & 1.86 & $2 \cdot 48$ \\
\hline & $0 \cdot 15$ & $1 \cdot 22$ & 1 & $i$ & 1 & 1.67 & 0.55 & 1.42 & 1 \\
\hline & $0 \cdot 2$ & 1 & $0 \cdot 18$ & 1 & 1 & 1 & $0 \cdot 16$ & 1.54 & 1 \\
\hline \multirow[t]{4}{*}{ (h) Chromobacterium sp. } & 0.05 & 1.64 & $2 \cdot 2$ & 1 & 1 & 1 & $2 \cdot 53$ & $0 \cdot 56$ & $0 \cdot 38$ \\
\hline & $0 \cdot 1$ & 1 & 1.89 & 1 & 1 & 1 & 1.46 & 0.72 & 0.54 \\
\hline & $0 \cdot 15$ & 1 & $1 \cdot 18$ & l & $1 \cdot 29$ & 0.43 & 0.54 & 1 & 0.41 \\
\hline & 0.2 & 0.74 & 0.75 & 0.86 & $1 \cdot 21$ & 0.33 & 0.6 & 0.66 & 0.86 \\
\hline
\end{tabular}

treatment. Protease also removed attached cells of P.fluorescens, E. cloacae and Chromobacterium sp. from the PD surface. Sodium periodate $(1 \%, w / v)$, which would denature exopolysaccharide at cell surfaces, detached both E. cloacae and the Chromobacterium sp. (Table 3) from the PD surface. The detachment of the Flexibacter sp. (Table 3) did not increase with any of the treatments or surfaces.

\section{Effect of hacterial growth rate and the presence of complex nutrients on bacterial attachment}

Two concentrations of PYE medium were used to determine the effect of complex nutrients on bacterial attachment. There was a large variation in the effects depending upon surface, organism and bacterial growth rate (Table 4) (NB the data in Tables 4 and 2 were obtained using the same culture and attachment procedures and can thus be directly compared).

The PD $I_{\mathrm{a}}$ and TCD $I_{\mathrm{a}}$ values indicated that either an increase or a decrease in attachment could result from the presence of nutrients, depending on the solid substratum and the concentration of nutrients present. Moreover, the $5 \mathrm{~min}$ and $60 \mathrm{~min} I_{\mathrm{a}}$ values for the two surfaces did not necessarily show the same effect, e.g. the $I_{\mathrm{a}}$ value for attachment of $P$. fluorescens to PD $\left(D=0.15 \mathrm{~h}^{-1}\right)$ with PYE and $5 \mathrm{~min}$ attachment showed an increase in attachment over the control, but at $60 \mathrm{~min}$ there was a reduction in $I_{\mathrm{a}}$ with PD (Table $4 a$ ). An example of the effect of growth rate on the type of effect was observed in Chromobacterium sp. attached for $60 \mathrm{~min}$ in PYE, which showed an increase in attachment to PD at a growth rate of $0.05 \mathrm{~h}^{-1}$ but a decrease at $D=0 \cdot 15 \mathrm{~h}^{-1}$ (Table $4 b$ ). The treatments also affected the rate of increase in attachment from $5 \mathrm{~min}$ attachment to that at $60 \mathrm{~min}$, e.g. Chromobacterium sp. $\left(D=0.05 \mathrm{~h}^{-1}\right)$ showed a far larger rate of attachment in PYE than in the buffer control (Table $4 b$ ). E. cloacae showed similar types of variation in attachment in the presence of PYE media. 
The only species to show a consistent relationship between attachment and nutrient concentration was Flexibacter sp. The presence of nutrients at all but the lowest growth rate, where there was no apparent effect, caused a decrease in attachment to both PD and TCD surfaces after $60 \mathrm{~min}$ attachment.

Water contact angle measurements $\left(\theta_{\mathrm{H}_{2} \mathrm{O}}\right)$ on clean PD and TCD were $90^{\circ}$ and $59^{\circ}$ respectively. Nutrient-treated $\mathrm{PD}$ and TCD had reduced $\theta_{\mathrm{H}_{2} \mathrm{O}}$; after $\frac{1}{2} \mathrm{PYE}$ treatment $\theta_{\mathrm{H}_{3} \mathrm{O}}$ was PD $72.5^{\circ}$ and TCD $18.5^{\circ}$ and after PYE treatment $\theta_{\mathrm{H}_{3} \mathrm{O}}$ was PD $80^{\circ}$ and TCD $13^{\circ}$. The liquid surface tension of HEPES, $\frac{1}{2}$ PYE and PYE was $7.0,6.6$ and $6.4 \mathrm{~J} \mathrm{~cm}^{-2}$ respectively.

\section{DISCUSSION}

There was a wide variation in levels of bacterial attachment to the solid substrata PD and TCD for P. fluorescens, E. cloacae, Chromobacterium sp. and Flexibacter sp. with changes in carbon source and growth rate. The composition of the growth medium has been found previously to be important in subsequent levels of bacterial adhesion, though the basis for the effect was largely unexplained (Zvyagintsev, 1959). Differences in the attachment of Chromobacterium sp. were found after growth for $24 \mathrm{~h}$ and $48 \mathrm{~h}$ in batch cultures with different carbon source and carbon: nitrogen ratio. This illustrates the significance of growth phase in the attachment process, an effect previously demonstrated (Fletcher, 1977).

The variations in levels of attachment for the isolates were accompanied by changes in physico-chemical properties of the bacterial cell surfaces detected by changes in $\theta_{\mathrm{s}}$ and HIC and EIC interactions. Thus, phenotypic changes in surface properties may lead to changes in attachment ability, but these responses can vary with species. There was no general relationship between growth conditions, cell surface adhesives and attachment ability that was applicable to all species. The phenotypically-induced changes in the cell surface physico-chemistry of the four bacterial species were almost certainly related to changes in macromolecular composition and structure of the cell surfaces. Differences in cell surface macromolecular composition have been shown previously to affect bacterial attachment (Hogt et al., 1982; Pringle et al., 1983).

Depending on the type (e.g. hydrogen bonding, charge and hydrophobic interactions) and number of physico-chemical interactions between the solid surface and a bacterial surface, attachment may be increased or decreased by changes in the bacterial surface if adhesive interactions are increased or reduced, respectively. TCD has a higher negative charge and is more hydrophilic than PD and, therefore, adhesive interactions between the two substrata and a particular cell surface would be different. Thus, changes in bacterial surface characteristics could be expected to affect differentially the levels of attachment to the PD and TCD surfaces, as was observed.

The synthesis of protein did not appear to be a significant feature in maintaining adhesion for any of the freshwater isolates investigated once they had attached to the substratum, as the presence of chloramphenicol caused no detachment. Chloramphenicol, however, by inhibiting the production of enzymes, may interfere with the synthesis of other potentially adhesive molecules, such as polysaccharides. This suggests that the synthesis of fresh cell wall material is not required to maintain adhesion over short periods, i.e. $1 \mathrm{~h}$. Elsewhere, inhibitors of protein synthesis have been shown both to have no effect on bacterial adhesion (Marshall, 1974) and to inhibit adhesion (Paul, 1984).

The significance of exopolysaccharides in adhesion was evaluated by treatment with sodium periodate, which denatures polysaccharides by oxidizing and cleaving vicinal hydroxyl groups characteristic of carbohydrate molecules. The possibility of a protein adhesive was tested by treatment with a non-specific protease. The effects of periodate and protease on bacterial detachment differed between the three non-gliding bacteria and Flexibacter sp., and with the solid substratum. Generally, Flexibacter sp. detached least. The effect of proteolytic enzymes has been found previously to vary with bacterial species and substratum (Fletcher, 1980). Periodate treatments have been used to detach successfully several bacterial types (Corpe, $1974 a$; Fletcher, 1980). 
Apparently, both proteins and exopolysaccharides were involved in the attachment of $E$. cloacae and Chromobacterium sp. to the PD surface because both protease and sodium periodate treatments increased their detachment. P. fluorescens showed detachment from both surfaces in the presence of protease but not with periodate, suggesting that proteins and not exopolysaccharides may have been significant contributors to the attachment of this species. However, the lack of bacterial detachment after protease or periodate treatment, e.g. for Flexibacter sp., need not indicate necessarily that proteins or polysaccharides were not involved in the bacterial attachment interactions. The particular configuration adopted by cell surface proteins interacting with a substratum, and the closeness of the interaction may have caused differences in the efficacy of degradative enzymes. The type of proteolytic enzymes used in desorption studies has been found to affect detachment differently (Corpe, 1974a), as has the temperature of incubation during the desorption (Fletcher \& Marshall, 1982). Further, periodate does not degrade all carbohydrates, requiring the presence of vicinal hydroxyl groups, and it can also be excluded by highly charged polymers (Rambourg, 1971).

Attachment of the four freshwater bacteria was less disrupted by protease and periodate on the TCD than on the PD surface. The more hydrophilic TCD surface may have produced firmer bacterial adhesion than the relatively hydrophobic PD substratum since hydrophilic surfaces, i.e. high energy high polarity surfaces, tend to absorb macromolecules more strongly than low energy hydrophobic surfaces (Baier, 1981). It is possible that different bonding types or different macromolecular constituents were involved in attachment interactions with the different solid substrata. Separate attachment mechanisms for PD and TCD have previously been suggested (Fletcher \& Marshall, 1982). Alternatively, adhesion to the hydrophilic TCD surface may have resulted in a molecular configuration of cell surface groups less accessible to disruption.

The presence of nutrients modified levels of bacterial attachment to the solid surfaces, the effect varying with the nature of the substratum and the particular bacterial species involved. Inhibition of attachment has been found with undefined macromolecules (Fletcher \& Loeb, 1979) and with several different proteins (Fletcher, 1976). In some cases protein has promoted adhesion (Meadows, 1971).

The presence of PYE in the liquid phase would have two physico-chemical effects. First, the liquid surface tension changes because of the interaction between water molecules and solutes, which varies with the solute and its concentration; e.g. $\frac{1}{2}$ PYE and PYE had different surface tensions. The influence of liquid surface tension on bacterial attachment has been discussed by several workers (Fletcher \& Pringle, 1985), particularly in relation to thermodynamic predictions of bacterial attachment (Absolom et al., 1983). Second, a conditioning layer will form on the substrata, an interaction favoured by a reduction in interfacial free energy, dictating the surface characteristics presented to the bulk phase.

Conditioning film formation on PD and TCD by PYE was indicated by $\theta_{\mathrm{H}, \mathrm{O}}$ measurements, though the $\theta_{\mathrm{H}_{0} \mathrm{O}}$ values cannot be directly related to surface energies since the films were airdried. The $\theta_{\mathrm{H}, \mathrm{O}}$ changes on TCD were greater than those on PD and both varied with the concentration of PYE solutions, possibly indicating differences in the conditioning film.

The decreased and increased levels of bacterial adhesion for some of the PYE treatments may be explained, partially, by the effects of a conditioning film. For example, a reduction of interfacial free energy (Fletcher \& Marshall, 1982) and osmotic effects (Lips \& Jessup, 1979) caused by a conditioning film would tend to lower attachment, while polymer bridging (Lips \& Jessup, 1979) and a change in substratum bonding capacity might increase attachment. The effect of PYE on bacterial adhesion, differed between $5 \mathrm{~min}$ and $60 \mathrm{~min}$ attachment. Conditioning films increase in thickness with time (up to a limiting thickness) (Baier, 1980), and this may have resulted in the differences in attachment with incubation time.

If physiological activity was involved in bacterial adhesion (Fletcher \& Marshall, 1982), then the presence of nutrients in the attachment suspension and the increased growth rate in the chemostat cultures may have affected bacterial adhesion through changes in bacterial physiological processes and activity. However, increased bacterial physiological activity did not necessarily increase subsequent bacterial attachment. The major role of physiological activity in bacterial adhesion, for the species investigated, appeared to be indirect, through changes in cell 
surface characteristics. As the cell surface characteristics of the bacteria changed with growth rate so did the attachment interactions when PYE was present in the suspending medium (bacterial cell surface characteristics shown in Table 2 were those of the cells undergoing adhesion in the PYE media, Table 4). Physiological activity, however, may have been more closely related to the attachment of the Flexibacter sp., the gliding bacterium, since its levels of attachment did increase with growth rate.

As the surface characteristics of the isolates changed there was a subsequent change in their adhesion to solid surfaces. However, no one physico-chemical cell surface property correlated with attachment numbers nor thus appeared dominant in the attachment interactions. This suggests a balance of physico-chemical factors were probably involved in net attachment (or detachment). Observations on the adhesion of other bacterial species have also suggested the involvement of more than one type of adhesive interaction (Feldner et al., 1983; Kjelleberg \& Hermansson, 1984).

The different patterns in bacterial adhesion to a substratum shown by $P$. fluorescens, $E$. cloacae, Chromobacterium sp. and Flexibacter sp. in response to changes in growth rate, nutrient conditions, the presence of organic molecules during attachment and the substratum underlines a major difficulty in the extrapolation of laboratory data to environmental conditions. However, it is probable that the changes in nutrient conditions in natural aquatic habitats will affect the attachment of individual bacterial species differently, resulting in differences in the species composition of a newly developed biofilm. There is some evidence for this both in marine and in freshwater environments (Corpe, 1974 $b$; Baker, 1984) and in river water chemostat enrichment cultures (Ellwood et al., 1982; Wardell et al., 1980).

This work was funded by a SERC-CASE Studentship. We wish to thank Dr John Baker for his patience and advice during this work.

\section{REFERENCES}

Absolom, D. R., Lamberti, F. V., Policova, Z., ZingG, W., van Oss, C. J. \& Neumann, A. W. (1983). Surface thermodynamics of bacterial adhesion. Applied and Emironmental Microbiology 46, 90 97.

BAIER, R. E. (1980). Substrate influences on adhesion of microorganisms and their resultant new surface properties. In Adsorption of Microorganisms to Surfaces, pp. 59-104. Edited by G. Bitton \& K. C. Marshall. New York: John Wiley \& Sons.

BAIER, R. E. (1981). Early events of micro-fouling of cell heat transfer equipment. In Fouling of Heat Transfer Equipment, pp. 293-304. Edited by E. F. C. Somerscales \& J. G. Knudsen. Washington, DC: Hemisphere Publishing Co.

BAKER, J. H. (1984). Factors affecting the bacterial colonization of various surfaces in a river. Canadian Journal of Microbiology 30, 511-515.

BaszKin, A. \& LymanN, D. J. (1980). The interaction of plasma proteins with polymers. I. Relationship between polymer surface energy and protein adsorption and desorption. Journal of Biomedical Materials Research 14, 393-403.

CORPE, W. A. (1974a). Detachment of marine periphytic bacteria from surfaces of glass slides. Developments in Industrial Microbiology 15, 281-287.

CORPE. W. A. (1974b). Periphytic marine bacteria in the formation of microbial film on solid surfaces. In Effects of the Ocean Environments on Microbial Actirities, pp. 397-417. Edited by R. Colwell \& R. Morita. Baltimore: University Park Press.

Dahlbäck, B. O., Hermansson, M., KJelleberg, S \&
NoRkRaNs, B. (1981). The hydrophobicity of bacteria - an important factor in their initial adhesion at the air-water interface. Archines of Microbiology 128, 267-270.

DEXTER, S. C. (1977). Influence of substrate wettability on the formation of bacterial slime films on solid surfaces immersed in natural sea water. In Proceedings of the 4th International Congress on Marine Corrosion and Fouling, pp. 137-144. Edited by V. Romanovsky. Boulogne: Centre de Recherches et d'Etudes Oceanographiques.

EIRICH, F. R. (1977). The conformational states of macromolecules adsorbed at solid-liquid interfaces. Journal of Colloid and Interface Sciences 58. 423-436.

Ellwood, D. C. \& TeMPEST, D. W. (1972). Effects of environment on bacterial wall content and composition. Advances in Microbial Physiology 7, 43-47.

Ellwood, D. C., Keevil, E. C., Marsh, P. D., Brown, C. M. \& W ARdell, J. N. (1982). Surface associated growth. Philosophical Transactions of the Royal Society. Series B 297, 517-532.

FeldNER, J., BREDT, W.\& KaHNE, I. (1983). Influence of cell shape and surface charge on attachment of Mycoplasma pneumoniae to glass surfaces. Journal of Bacteriology 153, 1-5.

FleTCHER, M. (1976). The effects of proteins on bacterial attachment to polystyrene. Journal of General Microbiology 94, 400-404.

FLETCHER, M. (1977). The effects of culture concentration and age, time and temperature on bacterial attachment to polystyrene. Canadian Journal of Microbiology 23, $1-6$. 
Fletcher, M. (1980). Adherence of marine microorganisms to smooth surfaces. In Bacterial Adherence, pp. 345-374. Edited by E. H. Beachey. London: Chapman \& Hall.

FletChER, M. \& LOEB, G. I. (1979). Influence of substratum characteristics on the attachment of a marine pseudomonad to solid surfaces. Applied and Environmental Microbiology 37, 67-72.

Fletcher, M. \& Marshall, K. C. (1982). Bubble contact angle method for evaluating substratum interfacial characteristics and its relevance to bacterial attachment. Applied and Environmental Microbiology 44, 184-192.

Fletcher, M. \& Pringle, J. H. (1985). The effect of surface free energy and medium surface tension on bacterial attachment to solid surfaces. Journal of Colloid and Interface Science 104, 5-14.

hogt, A. H., Feijen, J., Dankert, J. \& DE VRies, J. A. (1982). Adhesion of Staphylococcus epidermidis and Staphylococcus saprophyticus onto FEP-teflon and cellulose acetate. In Biomedical Polymers. Proceedings of the Biological Engineering Society, pp. 39-47. London: The Biological Engineering Society.

HorRocks, D. L. (1977). The H Number Concept. Technical report 1095 NUC 77-IT of the Scientific Instruments Division, Beckman Instruments.

Jarman, T. R., Deavin, L., Slocombe, S. \& RigheLATO, R. C. (1978). Investigation of the effect of environmental conditions on the rate of exopolysaccharide synthesis in Azotobacter vinelandii. Journal of General Microbiolog.' 107, 59-64.

KJelleberG, S. \& Hermansson, M. (1984). Starvationinduced effects on bacterial surface characteristics. Applied and Environmental Microbiology 84, 497-503.

LiPs, A. \& Jessup, N. E. (1979). Colloidal aspects of bacterial adhesion. In Adhesion of Microorganisms to Surfaces, pp. 3-27. Edited by D. C. Ellwood, S. Melling \& P. Rutter. London: Academic Press.

LoEb, G. I. \& Neinof, R. A. (1975). Marine conditioning films. In Applied Chemistry at Protein Interfaces. Adtances in Chemistry Series 145, pp. 319-335. Edited by R. E. Baier. Washington, DC: Applied Chemistry Society.

Marshall, K. C. (1967). Electrophoretic properties of fast and slow growing species of Rhizobium. Australian Journal of Biological Sciences 20, 429-438.

Marshall, K. C. (1974). Mechanism of adhesion of marine bacteria to surfaces. In Proceedings of the $3 r d$ International Congress on Marine Corrosion and Fouling. pp. 625-633. Edited by R. F. Acker, B. F. Brown, J. R. DePalma \& W. P. Iverson. Evanston, Illinois: Northwestern University Press.

Meadows, P. S. (1971). The attachment of bacteria to solid surfaces. Archives of Microbiology 75, 374-381.

NORDE, W. \& LYKLEMA, J. (1978). Adsorption of proteins from aqueous solution on negatively charged polystyrene surfaces. In Ions of Macromolecular and Biological Systems. Proceedings of the 29th Symposium of Colston Research Society, pp. 11-33. Edited by D. H. Everett \& B. Vincent. Bristol: Biotechnica.

Paul, J. H. (1984). Effects of antimetabolites on the adhesion of an estuarine Vibrio sp. to polystyrene. Applied and Environmental Microbiology 48, 924-927.

PEDERSON, K. (1980). Electrostatic interaction chromatography, a method for assaying the relative surface charges of bacteria. FEMS Microbiology Letters 12 , 365-367.

Pethica, B. A. (1980). Microbial and cell adhesion. In Microbial Adhesion to Surfaces, pp. 19-45. Edited by R. C. W. Berkeley, J. M. Lynch, J. Melling, P. R. Rutter \& B. Vincent. Chichester: Ellis Horwood.

Plummer, D. T., James, A. M., Gooder, H. \& MAXTED, W. R. (1962). Some physical investigations of the behaviour of bacterial surfaces. V. The variation of the surface structure of Streptococcus pyogenes during growth. Biochimica et biophysica acta 60, 595-603.

Pringle, J. H. \& Flftcher, M. (1983). Influence of substratum wettability on attachment of freshwater bacteria to solid surfaces. Applied and Environmental Microbiology 45, 811-817.

Pringle, J. H., Fletcher, M. \& Ellwood, D. C. (1983). Selection of attachment mutants during the continuous culture of Pseudomonas fluorescens and relationship between attachment ability and surface composition. Journal of General Microbiology 129 , 2557-2569.

RAMBourg, A. (1971). Morphological and histochemical aspects of glycoprotein at the surface of animal cells. In International Review of Cytology, vol. 31, pp. 57-114. Edited by G. H. Bourne \& J. F. Danielli. New York \& London: Academic Press.

RosenBERG, M. (1981). Bacterial adherence to polystyrene: a replica method of screening for bacterial hydrophobicity. Applied and Environmental Microbiology 42, 375-377.

ROSENBERG, M., RotTom, S. \& Rosenberg, G. (1982). Cell surface hydrophobicity of smooth and rough Proteus mirabilis strains as determined by adherence to hydrocarbons. FEMS Microbiology Letters 13, $167-169$.

Wardell, J. N., Brown, C. M. \& Ellwood, D. C. (1980). A continuous culture study of the attachment of bacteria to surfaces. In Microbial Adhesion to Surfaces, pp. 221-230. Edited by R. C. W. Berkeley, J. M. Lynch, J. Melling, P. R. Rutter \& B. Vincent. Chichester: Ellis Horwood.

Zvyagintsev, D. G. (1959). Adsorption of microorganisms by glass surfaces. Microbiology 20, 104108. 